\title{
IMPERIAL FANTASIES: IMAGINING CHRISTIAN EMPIRE \\ IN THREE FOURTEENTH-CENTURY VERSIONS OF THE BOOK OF SIR JOHN MANDEVILLE
}

\section{Introduction}

Investigating notions of empire in pre-modern texts can be a tricky task. As scholars of empire and medievalists alike have shown, what was considered to be 'empire' or 'an empire' in the Middle Ages is not identical - though clearly etymologically and conceptually related - to what is meant now, and the same is true for related terms. ${ }^{1}$

Historians have noted that some of the usual ways of defining empire in historical and structural analyses - a rimless wheel comprised of a hub and spokes; a dominant core and a dominated periphery, often established by or reliant on violence - fit uncomfortably with some entities that are considered to be, or considered themselves to be, empires in the Middle Ages. 'Empire', imperium, and cognate terms in the Middle Ages, scholars point out, could be used exclusively to mean the Holy Roman Empire; could retain their Roman meaning of right to command (imperium); could refer to the specific right of rulership believed to be inherited first by Constantinople, then by the Franks, in the person of Charlemagne, from Roman imperial rule; they could refer to territories acquired by conquest or far-flung possessions; or simply a territory governed by a sovereign ruler. An empire could exist without an emperor, and vice versa. ${ }^{3}$ As Reynolds notes, the combination of difference from and overlap with modern usages can create difficulties for those engaged in investigating and comparing empires in the Middle Ages. However, the works of scholars such as Robert Folz and James Muldoon show us that the history of thought concerning empire in the Middle Ages can be productively investigated from a different perspective. Folz's and Muldoon's usage-based, conceptual-historical approaches - particularly influential on this article - aim instead to trace the meanings and connotations of empire in particular spaces, contexts, and situations. ${ }^{4}$ Nonetheless, works like those of Folz and Muldoon are political and legal, topdown histories. They tell us what powerful or influential thinkers, papal and imperial courts, and their propagandists thought or wanted others to think about 
empire. As Leonard Scales has pointed out, though, it is not reasonable to assume that imperial ideologies simply radiated out from propaganda produced by their proponents to be passively absorbed by 'inert populations'. ${ }^{5}$ To assume this would be to entirely strip agency from all members of an empire's polity other than its rulers. And, as Peter Crooks has observed, for those who considered themselves (willingly or unwillingly) part of one, empire was not only a political structure, but also, following Benedict Anderson's formulation, an 'imagined community'. ${ }^{6}$ Like any other imagined community, imperial communities were continually produced, contested, and renegotiated in locally specific, differentiated ways.

In order to understand this process of production, contestation, and renegotiation, it helps to turn to culture, and, specifically, texts. It is not news, of course, that literary studies can advance our understanding of imperialism's social and cultural dimensions. In medieval studies, the trajectory of Robert Folz's work on the Holy Roman Empire indicates the centrality of the study of cultural representations to an understanding of such phenomena. Folz's magisterial cultural study Le Souvenir et la légende de Charlemagne dans l'Empire germanique médiéval preceded his political study, The Concept of Empire in Western Europe from the Fifth to the Fourteenth Century, by three years and helped lay the conceptual foundations for it. ${ }^{7}$ Numerous books and articles have engaged with questions such as medieval cultures' senses of their relationships with empires past, and with perceived cultural imperialism and resistance to it in the transmission and reception of medieval texts. ${ }^{8}$ Recently, Matthew Gabriele's Empire of Memory has traced how notions of empire from the Carolingian era to the eleventh century were bound up with their creators' interpretations of its past, and specifically Charlemagne. To speak of the first crowned western Christian emperor was 'a way of saying something about a universal community of Christians, that community's special place in God's eyes, and your relationship to that community in the arc of sacred history. .' In the schema that Gabriele delineates, in which cultural productions are simultaneously sites of contestation between memory and history and opportunities to remake the relationship between oneself, one's community, and an imagined universal Christian empire, the reception history of visions of empire takes on a new significance. This article seeks to show how close attention to one such history can nuance our understanding of how empire was produced as a concept, an ideal, and a community; how notions of empire were renegotiated in locally and temporally specific contexts; how mythologized histories of empire were contested and remade as texts crossed political, cultural, and linguistic borders; and how these could be mobilized in attempts to shape the present and the future.

The Book of Sir John Mandeville is a particularly valuable text with which to undertake this kind of enquiry. It was probably the most widely read geographical text of its day, certainly in the sense that its popularity cut across reading 
communities of different languages and social and cultural backgrounds, from merchants and laypeople to clerics to kings. ${ }^{10}$ Moreover, as the detailed analysis below of one of the two earliest versions of the text shows, Mandeville displays a close and informed interest in the history and legitimacy of empires, and in changing power relations in its contemporary world. However, it is also a very problematic text. Where the Book might have been written and by whom are questions of seemingly endless but often unproductive debate, ${ }^{11}$ and its nature and purpose are no less contested. It is well known that the text is not the account of a wandering knight's travels that it purports to be, but an extensively reworked amalgamation of a wide range of geographical source texts. ${ }^{12}$ Interpretations that attempt to tease out the Book's aims range from wilfully playful, self-conscious work of fiction to forerunner of modern geographical writing, and encompass pretty much everything in between. ${ }^{13}$ Moving away from this kind of genre scholarship, however, much recent work on the text has focused - not wrongly, I should make clear - on its open and enquiring attitude to regional and human diversity, its willingness to hold up a critical mirror to Latin Christendom and, in the words of Karma Lochrie, to 'provincializ[e] Europe' in a manner that, she argues, betrays a 'cosmopolitan' world view. ${ }^{14}$

However, aim- and genre-based arguments of this kind tend to share the weakness, noted by Kohanski back in 200I, that they are based on a fixed idea of what The Book of Sir John Mandeville is, and that fixed idea is frequently formed following analysis of a single version of the text, often the widely available but somewhat unrepresentative English translation known as the Cotton Version. ${ }^{15}$ The 'multi-textual' nature of the Book, so carefully demonstrated by Higgins in I997, also needs to be considered. Higgins's pithy explanation of the meaning of his coinage - characterized not just by intertextuality but also by 'distinctive intratextual multiplicity' - alerts us to the need to consider two distinct issues that complicate the picture of a 'cosmopolitan' text. ${ }^{16}$ Firstly, as a text that draws on a wide variety of quite disparate (though sometimes substantially repurposed and rewritten) earlier texts, Mandeville even in its earliest known forms bears traces of the perspectives of its sources. Its perspective is not singular, and is not entirely its own. Secondly, we need to bear in mind Higgins's observation that this 'medieval multi-text' exists not so much as a textual tradition but - to borrow Higgins's vocabulary - as an isotopic structure characterized by myriad similar-but-different textual versions. In common with other types of text valued more for their 'continued functionality', as Bella Millett has put it in another context, than for their 'textual integrity, or indeed authorial intention', Mandeville was often extensively adapted in the process of transmission and translation. ${ }^{17}$ As Kohanski puts it, 'popular manuscripts such as the Book were by nature in a constant state of flux: scribes, translators, and redactors all treated alterations to such texts as potential enhancements' ${ }^{18}$ Each 'isotope' thus balances an element 
of fidelity to its source version with 'potential enhancements' adapting it to its target language, audience, context, and purpose. It follows that scholars need to balance attention to what can be ascertained of the aims and purposes of the text's earliest versions with attention to its locally and temporally specific modes of reception.

Through attention to an insular version of Mandeville (c.1356) and two adaptations produced by the end of the fourteenth century, this article seeks to trace some of the cultural work that memories, histories, and myths of empire did in specific political circumstances and historical moments. It shows how the earliest textual versions' vision of a declining western Christian empire, challenged by great imperial powers in the East and surpassed in efficacy by an expansionist Church, is contested by two redactors who encounter it half a century later in the Prince-Bishopric of Liège, within the Holy Roman Empire. Their rewriting of their contemporary world also involves, as I will show, a rewriting of the history of Christian empire, a rewriting that, to repurpose in a different context Gabrielle Spiegel's observation on the chroniclers of Saint-Denis, turns the past into 'an explanatory principle, a way of ordering and making intelligible events separated by vast distances of time'. ${ }^{19}$

While normally considered marginal to the textual tradition of Mandeville, these later redactions were extremely significant in its fourteenth- and fifteenthcentury reception. Although there are only six surviving manuscripts of the first of these, the so-called Version liégeoise or Liège version of Jean d'Outremeuse, the second of the two redactions, the so-called Vulgate Latin translation, based directly upon it, was widely diffused across Europe, and particularly in the Empire. Both versions then influenced a further immensely popular vernacular translation: the German version of Otto Von Diemeringen. ${ }^{20}$ These redactions are thus more significant in their own right than is normally recognized. Indeed, assuming that empire in the Middle Ages was, as Crooks suggests, an 'imagined community' as much as a political structure, but, as Gabriele indicates, one whose representations are 'tethered to local conditions', these redactions can provide an insight into some of the processes through which an imaginatively constituted empire could be sustained, contested, and reshaped, in part by reshaping its 'explanatory' past. ${ }^{21}$ They show, in fact, how the process of rewriting provided an opportunity to renegotiate one's own or one's community's relationship with empire and imperial rule.

\section{Visions of empire in the Insular Mandeville}

Before turning to the resistant 'counter versions' that will be the subject of the later sections of this article, it is first necessary to outline the state of contemporary empires in the world according to the earliest Mandeville versions on which they 
drew. ${ }^{22}$ The specific early text examined here is the so-called Insular version, one of the two French texts that scholars have identified as potentially representing the earliest textual tradition. ${ }^{23}$ Insular by name, this version is hardly insular in nature; it is highly attuned to recent shifts in global power relations and shows a particular interest in questions of Christian authority and influence around the world. The text was produced in the I350s, just as the intense flurry of missionary activity in Asia that characterized the thirteenth and fourteenth centuries was coming to an end, and just before the fall of the Mongols (Yuan) and the accession of the Ming Dynasty rendered China much more difficult for European travellers to access. ${ }^{24}$ The Book, however, drew on knowledge gathered over a century and a half of contact between sacred and secular European potentates and rulers in the East. Its geographical range and its deployment of thirteenth- and early fourteenth-century eyewitness sources forced it to consider the balance of power not within Europe, but across the world. Through the work's varied accounts of imperial powers near and far, past and present, one can trace the outlines of a particular vision of the spread of Christian empire across the world.

An examination of the usage of the terms empire and emperor in the Book shows that it reflects the multiplicity of sometimes overlapping, sometimes conflicting meanings and connotations of the term outlined by recent commentators. The Book's first references to imperial power appear in its description of Constantinople, the imperial capital of the Romans under Constantine and capital of the Eastern Roman Empire. The basis of the Byzantine emperor's imperial title was often questioned in the Latin West following Charlemagne's coronation, by which Leo III was held to have effected the translatio imperii: the transfer of the Roman Empire to western European, specifically Frankish, rule. ${ }^{25}$ Mandeville's account of Constantinople reflects a wider pattern of later medieval scepticism about the reality of the Byzantine emperor's imperial rule; it became a cliché among canon lawyers, according to Muldoon, that 'the Byzantine emperor was no more a true emperor than the king in a chess-set was a real king. ${ }^{26}$ Indeed, the Book's description is rich with symbolism of the translatio imperii away from Constantinople. The city's statue of Justinian, the great sixthcentury Eastern Roman emperor, once held a golden apple to signify his earthly 'seignurie' ('lordship', or imperium), but that apple has fallen, and cannot be replaced. ${ }^{27}$ Through this symbolism, the Byzantine Empire's claim to authority based on its inheritance of the imperial title from Rome is undermined. ${ }^{28}$ But Byzantium's claim to imperial status based on religious authority is undermined in the Book too. According to the Book, many of the sacred relics of Christ once held at Constantinople have passed to western Europe. This move is both result and symbol of the Byzantine Empire's decline. With the emperor forced by lack of funds to pawn holy relics to the Genoese, part of the Crown of Thorns, one of the crucifixion nails, and the head of the spear that pierced Christ's side and 
'plusours autres reliques sont en France en la chapel le roi' ('many other relics are in France in the chapel of the king') ${ }^{29}$ And, while the Byzantine emperor might claim that he retains the head of the Holy Lance, this sacred relic is split between France and Germany: the Emperor of Germany (the Holy Roman Emperor) has the shaft, Mandeville tells us, but the blade is at Paris. ${ }^{30}$ As Anne Latowsky and Matthew Gabriele have pointed out, in early medieval narratives of the life of Charlemagne, the transfer of Byzantine relics to the Frankish king functions to signal 'a shift in imperial primacy to the West'. ${ }^{31}$ Just such a transfer is signalled in Mandeville's account of Constantinople. In the following chapter, the Mandeville-author underscores the separation of this Byzantine Empire from the Latin Christendom to which its symbols have now passed. In response to overtures by Pope John XXII, the Greeks firmly reject the notion of obedience to the papacy. It therefore falls to the Byzantine emperor to appoint 'le patriarke les archevesques et les evesques' because 'il est sires de temporel et del espirituel en soun pais' ('the patriarch, the archbishops and the bishops'; 'he is both temporal and spiritual lord in his land'). ${ }^{32}$

Mandeville's description of the Byzantine Empire, then, on the one hand recalls the notion of universal Christian empire and the theory of its translation from East to West so central to much medieval thought on empire, but on the other undermines it. Certainly, the Book's account shows an Eastern Empire that has lost its imperium: that is, its imperial authority. ${ }^{33}$ However, the account by no means univocally supports the theory of that imperium's transfer to the Carolingian Empire, a theory that was central to the claims to authority and universal jurisdiction of a Holy Roman Empire that considered itself Charlemagne's successor. ${ }^{34}$ The relics of Christ are dispersed in the realms of the King of France and Emperor. The nominal Byzantine Emperor, moreover, submits to neither the temporal nor the spiritual lordship of the West. While the Eastern Empire has lost its imperial authority, then, whether and to whom that authority has been transferred is not made clear.

Having raised, then troubled, in its account of Constantinople, the notion of a universal Christian empire whose authority and legitimacy can be traced back, through the Eastern Empire, to ancient Rome, the Book moves on to discuss other contemporary empires and emperors beyond the borders of Christendom. The legitimacy of these empires is built on quite different foundations. These eastern empires are self-sufficient and powerful, and their rulers' claims to imperial status rest at least in part on their subordination, sometimes by military conquest, of other kingdoms. ${ }^{35}$ The Sultan of Egypt is described as 'sires de V roialmes qe il ad conquis et appropriez a luy par force' ('lord of five kingdoms that he has conquered and taken to himself by force'). ${ }^{36}$ The Emperor of Persia's imperial status, on the other hand, appears to be based in his rulership over the 'mointes pais', 'mointe cité', 'mointe ville', 'mointes terres' ('many countries, many cities, 
many towns, many lands') that one must traverse to pass through it, rather more than on the pre-eminence of a ruler who, the text mentions elsewhere, in fact holds his lands from the Great Khan. ${ }^{37}$ Nonetheless, at the great Silk Road city of Tabriz, this emperor 'prent plus en celle cité pur cause des marchandises, que ne fait le plus riche roy christien de mounde' ('takes more in that city on account of merchandise than the richest Christian king of the world'). ${ }^{38}$

Moving beyond Muslim lands, further east, we come to the two greatest empires delineated in the Book: the Christian empire of Prester John, and the vast, multi-ethnic, multi-religious Mongol empire of the Great Khan. The presentation of these Far Eastern empires seems designed to throw into relief the mutability of imperial power and to put grand ideals of universal Christian empire into contemporary global perspective. Mandeville's readers would most likely have already been familiar with the legendary empire of Prester John from the Letter and its many interpolations, so it is instructive to compare the Book's deployment of this figure with that of its major source. Bernard Hamilton has persuasively argued that the initial Letter was produced in the ambit of Holy Roman Emperor Frederick Barbarossa's court and was intended to function as a specular image of an idealized alternative social order in which Church and state function together harmoniously under the ultimate leader of a pious, ordained ruler: in short, that it presented an image of an imperial court matching Frederick's ideal. ${ }^{39}$ While Hamilton's account of the genesis of the Letter is not universally accepted, there are unquestionably parallels between the Letter's vision of Christian empire and the idealizing notion of the sacrum imperium that became a 'standard formula' under the Hohenstaufen emperor. ${ }^{40}$ Mandeville draws heavily on the Letter tradition for his account of Prester John's empire. ${ }^{41}$ However, compared with the priest-king's presentation in the Letter and its interpolations, his powers in Mandeville are surprisingly circumscribed. Prester John's apostolic Christianity is clearly differentiated in the Book as inferior to that of Latin Christendom. ${ }^{42}$ Whilst his title as emperor is supported by the fact that he has 'desouz ly mointes rois et mointes isles et mointes diverses gentz' ('beneath him many kings and islands and different peoples'), these lands are 'noun pas si riches comme cely de Grant Chan' ('not as rich as that of the Great Khan'). ${ }^{43}$ While the Book's priest-king is not the Great Khan's vassal, it is nonetheless clear that, following the major shift in world power brought about by the unification of the Mongol tribes and the establishment of the Mongol empire, the greatest emperor of the fourteenth-century world is the Great Khan:

Dessouz le firmament n'ad point de si grant signour ne de si puissant come est ly Grant Chan ne dessure terre ne dessous, qar ne Prestre Johan qe est emperour de la haute Ynde, ne ly Soudain de Babiloigne, ne l'emperour de Persie n'ad comparisoun a ly ne de puissance, ne de noblesse, ne de richesse, qar en tout ceo il passe touz les princes terrienz. ${ }^{44}$ 
(Beneath the firmament there is no lord so great or so powerful as the Great Khan, neither above the ground or below, because neither Prester John who is Emperor of Upper India, nor the Sultan of Babylon, nor the Emperor of Persia can compare with him in power, nobility, wealth, because he surpasses all earthly princes in all things.)

The empire of Prester John might be long-lived, devoutly Christian, legitimized by apostolic authority, but it is nonetheless no match for the conquering empires of the expanded world.

The narrator of the Insular version presents a world where Christian temporal power has fragmented and declined. The location of temporal lordship in the West is unclear, and no European Christian ruler can match the wealth and power of the Great Khan. The prologue, finally, pointedly ascribes the failure of Christians to retake the Holy Land to lack of unity among Christian lords who 'entendent plus a autry desheriter q'ils ne font a chalanger et a conquerre lour droit et propre heritage' ('prefer to disinherit one another than to declare war upon and conquer their rightful inheritance'). ${ }^{45}$

The Book, however, takes a very different view of the expansion across the world of Christian spiritual power, spread through the agency of the Church and its representatives, the missionary orders. It is important to recognize at this point that, while the Church did not refer to itself as an empire in the later Middle Ages, canon lawyers nonetheless developed in the twelfth and thirteenth centuries a detailed theory of universal Christian empire that, broadly speaking, separated imperial power from papal authority, and subordinated the former to the latter. ${ }^{46}$ In $\mathrm{I}_{302}$, a related doctrine of what is often known as papal imperialism found expression in Boniface VIII's bull Unam sanctam. According to this doctrine, holders of secular power must 'be subject to the Roman pontiff' as a condition of their salvation. ${ }^{47}$ The development of this universalist doctrine coincided with and influenced late thirteenth- and early fourteenth-century missions, which, under the licence of an admittedly sometimes reactive papacy, attempted to secure the obedience of non-Christian potentates and peoples alike to the Latin Christian Church and its leader. ${ }^{48}$ While papal universalist theories had lost influence by the time of the Book's composition, as a work that draws on a number of thirteenth- and fourteenth-century Dominican and Franciscan missionaries' narratives, the Book's vision of mendicant missions shows the influence of the ideals that inspired these. ${ }^{49}$ The Mandeville-author places the most optimistic spin possible on the outcome of thirteenth- and fourteenth-century diplomatic and missionary efforts in Asia, which it represents as a non-Christian world in the process of being spiritually recovered for Latin Christendom. ${ }^{50}$ The mendicant friars are represented as in the vanguard of attempts to convert non-Christians across the world. Mendicant houses and communities of 'bones Chrestiens' or non-heretical, meaning Latin, Christians - are now scattered across Asia, 
according to the Book. And, as Heng has noted, references in the Book's sources to communities of influential Nestorian (but in Latin eyes, heretical) Christians in India and China tend to be quietly ignored, throwing the activity of the Latin missionary orders further into relief. ${ }^{51}$ The Book also borrows and exaggerates Franciscan missionary Odorico da Pordenone's anecdotes concerning the Great Khan in order to represent him and his lands as on the cusp of conversion: the Khan is happy to hear the faith spoken of, permits Christians throughout his lands, and has many Christian servants 'convertyz a la bone foy' ('converted to the true faith'). ${ }^{52}$

That the earliest versions of The Book of Sir John Mandeville comment on the fragmentation and decline of Christian empire is perhaps not surprising, given that the book was written outside the contemporary borders of the empire and at a time when Holy Roman Emperor Charles IV has been described as engaged in the 'liquidation' of the empire as a political reality. ${ }^{53}$ At the same time, the French and English sovereigns were occupied by their own territorial conflict, with the result that the Insular Book features only passing references to any of these sovereigns as contemporary powers. Instead, the Book presents the work of bringing about a universal Christian order that reaches into the furthest regions of the known world as undertaken by the Church and its mendicant representatives.

\section{Rewriting empire in the Liège and Vulgate Latin Mandevilles at the end of the fourteenth century}

In the two adaptations of Mandeville produced in late fourteenth-century Liège, the Book's representations of contemporary empires and its vision of the future trajectory of Christian power in the world are almost entirely recast. Some of the changes in these resistant rewritings relate to changes in contemporary conditions; the papacy's focus on missions to Asia began to decline even before the Church was riven by the schism of 1378 . But these versions are also, in a sense, imperial reworkings. Whether produced in England or northern France, the early French versions of Mandeville were certainly produced beyond the historic and contemporary borders of the Holy Roman Empire. ${ }^{54}$ As it comes to be read in imperial lands, however, the Book claims the attention of readers whose sense of their community and its place in the world is shaped by the myth and memory, as well as the contemporary political reality, of the Holy Roman Empire. As the two versions examined here and their context are not well known, I begin this section with a brief introduction to these, and to the local and wider political context of their production.

The first of the two Liégeois reworkings chronologically is now generally agreed to be the handiwork of a Liégois cleric known as Jean d'Outremeuse. Normally known as the Version liégeoise or Liège version, it is a substantial 
rewriting of the Continental version that was circulating in the vicinity of Paris by the early I370s. ${ }^{55}$ The version's editors, Raelet and Tyssens, date its composition with reference to Jean's other works to between 1375 and I390, a date window that, with minor variations, is broadly accepted..$^{56}$ As well as being the redactor of the Liège Mandeville, Jean was the author of a chronicle by the name of the Myreur des hystors, a Geste de Liège, and a Geste d'Ogier, now lost. ${ }^{57}$ In all these works, Jean indulged both his intense patriotic pride in his home city and region and his extraordinary obsession with legends of Ogier the Dane, a paladin of Charlemagne who, over the thirteenth and fourteenth centuries, had developed from his minor role in the Chanson de Roland into a heroic protagonist in his own right. ${ }^{58}$ In his Myreur des hystors, Jean created links between Ogier and Liège, borrowed Ogier's legendary exploits in the Orient from existing Ogier romances, and substantially amplified and extended these using details from The Book of Sir John Mandeville. ${ }^{99}$ With ingenuity worthy of an internet hoaxer, Jean also revised the very book from which he borrowed so that Mandeville, too, contained multiple references to the great exploits of Ogier the Dane across the eastern reaches of the known world. As has been extensively demonstrated elsewhere, the works knit together neatly, with the Myreur even including a clear cross-reference to the Book. Jean d'Outremeuse cements the Book's link to his home city through interpolations suggesting that Jean de Mandeville returned to Liège, composing his book and dying there. ${ }^{60}$

The second revision discussed below is generally known as the Vulgate Latin or Hakluyt version. There are good reasons for accepting, with Ridder, the version's assertion that the translation was completed in Liège; in particular, the text's early reception shows a significant clustering around this area. ${ }^{61}$ Though a very widely read and influential version of Mandeville into the sixteenth century, the Vulgate Latin version is not very well known today, perhaps in part because, as Ridder notes, Latin translations from vernacular sources are rare in the period, and the manuscript transmission of the text is not well understood. ${ }^{62}$ While scholarship has been able to shed little clear light on the authorship of the version, it has provided a broad sense of when it was produced. Higgins and Tzanaki both suggested a production date of 1396 or later, while Deluz gave it a date of 1375 , all suggestions apparently firm, though based on reasoning that is not entirely clear. ${ }^{63}$ At any rate, the version must have been produced before Otto von Diemeringen completed a German translation that drew upon it in $1398 .{ }^{64}$

The location of both versions of the texts in Liège and their dating to the final decades of the fourteenth century enables us to consider how their representations of empire were inflected by their specific temporal and local contexts. Both versions were produced at a moment characterized by particular conflict and uncertainty within the Holy Roman Empire, in which they were produced, as well as by the papal schism that took place in 1378. Geographically 
close to the Carolingian historic heartland of Aachen (Aix-la-Chapelle), Liège was a prince-bishopric whose prince-bishop's secular authority derived directly from the emperor. ${ }^{65}$ Between 1378 and 1402 , when both redactions were almost certainly produced, however, the empire lacked an emperor. Though elected King of the Germans in 1368 , Václav IV of Bohemia never underwent the coronation ceremony that would have conferred on him the imperial title. Indeed, the Holy Roman Empire's powers and claims had diminished substantially since the days of the Hohenstaufen emperors, who laid claim, if only rhetorically, to universal imperium. ${ }^{66}$ Václav's father, Charles IV, had attempted to consolidate the central power of the empire politically, assert its independence from the papacy, and promulgate ideals of unity and of the 'indivisibility' of electoral principalities in his Golden Bull (I356) ${ }^{67}$ Nevertheless, he divided his own territories amongst his sons and other male relatives in a manner that seriously weakened the future king and would-be emperor Václav and the future position of the empire. ${ }^{68}$ Following his accession in 1378 , Václav became embroiled in a series of bitter conflicts and rivalries. ${ }^{69}$ Old imperial lands only relatively rarely saw their titular ruler, who on two occasions found himself imprisoned, once by his own nobles, and once by his brother and eventual successor Sigismund (1394; 1404). ${ }^{70}$ Though the justice of some of the accusations made against him has in recent years been disputed, Václav was ultimately accused by electors from the Rhineland of a variety of charges ranging from failure to resolve the papal schism to 'dilapidating' the empire in granting the dukedom of Milan to Giangalazzeo Visconti and, ultimately, of being 'inutilis' - incompetent or useless - in the empire. ${ }^{71}$ Indeed, it is noteworthy that, within imperial lands, Liège specifically experienced in the I390s a period of crisis and conflict regarding the extent of the prince-bishop's authority, one that was only resolved, long after Václav's death, following the intervention of his brother, emperor-elect Sigismund. ${ }^{72}$

The two Liège versions of Mandeville, I suggest below, are shaped by and intervene in this wider political context. It is particularly striking that both texts respond to the contemporary challenge of the rise of great eastern empires by recourse to Western Europe's own imperial past. I argue that their treatment of the past has affinities with that identified by Gabrielle Speigel in her study of thirteenth-century vernacular French chronicles' uses of the past. It is not just a 'repository of dreams and desires' and a 'consoling image of what was and is no longer', but also as a source of authority for their visions of the present and future. ${ }^{73}$

\section{Jean d'Outremeuse's Liège version}

Jean d'Outremeuse's Liège version makes a number of major changes to its Continental French source, but the most significant and arresting of these is his 
interpolation into the body of the text of fabricated anecdotes concerning the legendary Carolingian-era hero Ogier the Dane's fantastical adventures in the East. ${ }^{74}$ On the face of it, this is a peculiar thing to do; why fixate on an ultimately minor figure in the Charlemagne tradition in this way, a figure defined in earlier versions by his rebellion against his lord $?^{75}$ Scholars have broadly identified two strands in Jean's use of the figure across his histories and his revision of Mandeville, strands that we might call the local and the global. Focusing on Jean's uses of Ogier across his many works, Knud Togeby has observed that Jean d'Outremeuse, 'né et mort à Liège (I338-I400), a fait d'Ogier le Danois le personnage central de toute son œuvre, en faisant de lui le baron principal de Charlemagne et en le rattachant de multiples manières à la ville de Liège' ${ }^{76}$ Edina Bozoky, similarly, has suggested that, in making Ogier a founding figure for Liège in his historiographical works, Jean d'Outremeuse links his home city to a glorious past. However, in avoiding a direct link to Charlemagne - associated at the time with great German cities such as Cologne and Aachen - Jean contributes in her view à un rééquilibrage du prestige historique des villes du pays wallon par rapport aux villes allemandes'. ${ }^{77}$ Ogier is in these accounts a kind of local hero: one both linked to and drawing authority from the myths and legends that grew up around Charlemagne, and a figure whose legendary rebelliousness and independent achievements also distinguish him from the emperor, 'dont la figure reste secondaire' ${ }^{78}$ Indeed, in this respect, Jean's use of Ogier relates to wider trends in the character's development and social relations as identified by Emmanuele Poulain-Gautret; the legend's later incarnations aim, she argues, to establish a relationship of mutual dependence between Ogier and Charlemagne. This trend reflects a desire to rebalance the lord-knight relationship in a way more favourable to the subordinate partner, but that at the same time reinforces the lord's status. ${ }^{79}$ Indeed, in the Myreur des histors, Jean suggests that Ogier is an ancestor of all the major princes of his day, including 'les roys de Franche' and 'les empereres de Romme et de Consantinoble'. ${ }^{80}$ Ogier proves, then, a useful figure through which to renegotiate local-imperial political relationships both geographically and socially. It is the global strand of Jean's interpolations, however, that is particularly interesting for understanding how Jean remoulds his source's understanding of empire.

As the basis of his interpolations into Mandeville, Jean d'Outremeuse takes one strand of his hero's long and varied literary history, a strand in which he is a representative of 'une foi active, conquérante', fighting to extend Christendom on behalf of the putative founder of the Holy Roman Empire, Charlemagne. ${ }^{81}$ It is a tradition that draws and expands upon a strand in the historiographical and poetic material that had accrued around Charlemagne by the twelfth century, in which his imperial authority is related to military success against the pagans and either his pilgrimage to Jerusalem or his acquisition of relics from there. ${ }^{82} \mathrm{Among}$ 
the Capetians, Spiegel has noted, this invented crusading past was sometimes deployed to 'supply historical precedent, and hence legitimacy to royal crusading ventures' ${ }^{83}$ The Ogier traditions appear to be inspired by and in dialogue with such histories. In the early fourteenth-century Roman d'Ogier en décasyllabes, Ogier's adventures take him to Acre in an attempt to retake Jerusalem, and to Egypt where he ends up imprisoned by the sultan. ${ }^{84}$ In Jean d'Outremeuse's vision, these relatively limited adventures in the East are considerably expanded and Ogier becomes a figure who claims and marks out distant regions of the world for Christendom and, specifically, Charlemagne; he is responsible, for instance, for renaming the crusader fortress of Carach (Shoubak) as Mont Royal in token of his loyalty to the emperor. ${ }^{85}$ The Version liégoise then takes particular care to note how Ogier conquered lands and Christianized peoples across the Middle East, Asia, and Africa:

Les genz de ce pays que on appelle Samaritans furent premierement convertis et baptiziez des apostles, maiz puis furent destruis par le souldant et remis en leur loy. Et au temps Charles le Grant, roy de France et de Romme empereur, les [reconverti] et les fist baptizier Ogier le Danoys, qui fu un des .xij. pers de France et qui, oultre mer, sicomme je vous ay autreffoiz dit, conquist une foiz .xv. royaumes et une autre fois .xij., desqueilles terres et pays celle fu une. ${ }^{86}$

(The people of this country are called Samaritans and were first converted and baptized by the apostles, but then were destroyed by the sultan and returned to their law. And in the time of Charlemagne, King of France and Emperor of Rome, Ogier the Dane reconverted them and brought about their baptism. Ogier was one of the twelve peers of France and, beyond the sea, as I have told you elsewhere, conquered at one time fifteen kingdoms and at another time twelve, of which lands and countries this was one.)

In other words, eastern Mediterranean lands that had, by the time of Jean d'Outremeuse's writing, been wholly lost by the crusaders are transformed into former vassal states of an aggressively expansionist Carolingian Empire.

In the same vein, Jean d'Outremeuse also transforms the Book's account of the lands further to the east. Many eastern lands are identified in Jean's version as former conquests of Ogier, including the vast, wealthy lands of Cathay and Manzi, now under the control of the Great Khan, and those of the legendary Indian emperor Prester John. ${ }^{87}$ In Jean's retelling, Prester John is no longer a survival of an apostolic brand of Christianity that developed entirely separately from Latin Christendom, and certainly no longer functions as an alternative, idealized vision of western Christian empire. Instead, Prester John is a vassal of the Frankish empire; the first Prester John was Gondebuef of Frisia (an earlier Frankish conquest), a pious, Christian cousin of Ogier, installed to govern lands that Ogier had conquered and converted 'a l'espee' ('by the sword'). ${ }^{88}$ The fate of those who refused to convert is memorialized in the very name of the river 
Ganges. While in the Insular and Continental versions of the Book, the river Ganges is simply named, following an established medieval tradition, after an Indian king, in Jean d'Outremeuse's hand it becomes a marker of Ogier's violent conversion of the country; following his refusal to convert, the pagan king Gangens is drowned in the river, which thenceforth takes his name. ${ }^{89}$

As Tzanaki has observed, changes of this kind 'deliberately reverse the Book's attitudes to self-aggrandizing conquerors and pagan peoples', supporting an idea of the 'military propagation of Christianity' that is, as we have seen, 'foreign to the book's original author'. ${ }^{90}$ However, they do something else too: they present an alternative mythologized history of the Holy Roman Empire of which Jean d'Outremeuse's home region formed part. While Charlemagne had conquered lands stretching from Lombardy to Iberia, the idea that his empire extended into the eastern Mediterranean and beyond is, of course, pure fantasy. And, while the precise source of the Frankish emperor's imperial authority was the subject of protracted and ultimately unresolved debate, by the high and later Middle Ages it was most usually thought to derive either from his papal coronation as protector of the Church or from his status as successor to the Roman emperors, specifically Augustus and Constantine. ${ }^{91}$ His empire, however, is recast by Jean d'Outremeuse as one whose legitimacy is principally based in far-flung military conquests and religious conversion, on behalf of God but not necessarily or evidently sanctioned by the Church. ${ }^{92}$ The text implies that the early stages of this empire-building involved expansionist activities reminiscent in some significant ways of the high and late medieval European colonization practices outlined by Robert Bartlett. Bartlett has argued that the medieval process of colonization that shaped Europe was composed of independent agents, not normally acting under royal or imperial command, 'reproducing units similar to those in their homelands' in a process that most resembles 'a kind of cellular multiplication, of the cultural and social forms found in the Latin Christian core'. ${ }^{93}$ While Bartlett notes that, within the core areas of Western Europe, the 'new colonies of Holy Christendom' could become 'replicas without political subordination', relations between the 'more homogenous central zone' and the furthest reaches of European expansionist influence were 'not between equals: they involved domination and subordination, control and resistance..$^{94}$ The Liège version appears to reflect some elements of this recent history of European expansion, and projects them back into an imagined imperial past. Ogier's conquests are clearly his own, autonomously led; they benefit and add to the glory of, but are not purposefully directed by Charlemagne, who is a barely present shadow in the story. Indeed, particularly when combined with the Myreur's assertions about Ogier's royal and imperial descendants, they enhance Ogier's status relative to his lord. The expansionist activity in the Far East aims to replicate European structures: Ogier sets up monasteries, churches, and even rulers. But the pattern 
at times more closely reflects what Bartlett finds on what he terms the peripheries: a model of violent political subordination. That this neither reflects the usually diffused versions of the history of the Carolingian Empire of Jean's day nor the historical or contemporary practice of the Holy Roman Empire is not the point. Jean d'Outremeuse imagines an empire whose legitimacy is not in the gift of the papacy, but based in its conquest, subordination, and Christianization of vast areas of land and multiple peoples. But it is also a geographically differentiated vision of empire in which core territories - those in what Bartlett calls Europe's 'central zone' - work together; nominally subordinate rulers within the core enjoy autonomy and voluntarily contribute to empire's success, participating in a community of peers defined against subordinated outlying regions.

Of course, Jean's vision of an aggressively expansionist Christian empire is a reimagining of the past. But this reimagining is not a fantasy whose effects are limited to the past; the legacies of the past extend into the present and beyond. To understand this, it helps once again to turn to Gabrielle Spiegel's insights into the nature of medieval historiographers' engagements with the past. Spiegel has shown how, in medieval chronicles, the relationship between events was often animated not so much by cause and effect as we would understand these terms as by typology, following the model of the typological interpretation that had been so foundational to Christian biblical exegesis. Spiegel notes that, for many chroniclers:

By means of typological interpretation, the significance of the past is reaffirmed for the present; the old becomes a prophecy of the new and its predeterminant in the sense that its very existence determines the shape and the interpretation of what comes later. In this way, the past becomes an explanatory principle, a way of ordering and making intelligible events separated by vast distances of time. ${ }^{95}$

Jean d'Outremeuse's reimagining of the past, in his Mandeville and his historiographical work alike, foreshadows and legitimizes a future of violent Christian imperialism. For Jean, Christian empire has been far more successful in the East than suggested in the early Mandeville versions. In a significant alteration to his source, Jean insists that no lord is as great as the Great Khan 'fors seulement le Prestre Jehan' ('except only Prester John'). ${ }^{96}$ Ogier's 'véritable programme politico-religieux', bringing Christianization and conquest in tandem, still has impacts in the present; ${ }^{97}$ much of the work of conversion that in the Insular and Continental Mandeville texts is credited to mendicants is instead credited to the religious foundations that Ogier established. The Christians responsible for, for example, the key symbolic, Christianizing work of leading the Khan to revere the cross are 'religieux crestiens de[s] religions que Ogier le Danoys estora' ('Christian religious of the religious orders that Ogier the Dane created') ${ }^{98}$ But this imagined imperial past is one that contains within itself an 
imagined imperial future; Jean invents a Saracen prophecy that predicts the final completion of this programme. Ogier is not dead, it holds, but merely sleeping, and 'il revenra et si conquerra tout leur pays et convertira a la foy crestiene' ('he will return and conquer their entire country and convert them to the Christian faith'). ${ }^{99}$ The use of the 'sleeping king' motif here is particularly striking. Gabriele has argued that the legend of the Last Emperor, a great Christian ruler who would emerge in the Last Days to convert the whole world to Christianity by force and usher in the coming of the Antichrist, was closely attached in the eleventh century to Charlemagne, whose body was reported, when his tomb was opened in the year Iooo, to be in a form of 'suspended animation': not dead, but sleeping. ${ }^{100}$ This association raises the possibility that the Liège version is obliquely referencing an imperial vision of prophetic history built up around the mythologized figure of the empire's founding father. However, the marker of status is transferred from the emperor himself to his Liégeois paladin.

It is through the figure of Ogier, then, that the transformation of the Liège version's renegotiation of local-imperial and imperial-global relations emerges. The mid-fourteenth-century Insular Mandeville reflected a sense that secular Christian rulers had failed to bring about the Christianization of the world. The Liège version, on the other hand, imagines a world whose scattered Christian communities result from a period of bloody conquest. Responsibility for converting the world passes from the apostles not to the papacy - in the text's contemporary moment distracted by schism - but to the emperor and, notably, his representatives. Such Christianization of the East as has taken place has been achieved not so much by a distracted and disunified Church as through the continued influence and agency of Ogier, a local agent acting in voluntary partnership with an imperial ruler. But Jean's reimagined history is also typological and prophetic; the process will one day be completed, whether peacefully through the Christian foundations Ogier established under the aegis of the Carolingian Empire, or by the sword. Through the suggestion of a miraculous return, feared by the Saracens, Ogier implicitly challenges the primacy of the Holy Roman Empire's claimed founding father.

\section{Visions of the end of empire: the Vulgate Latin Mandeville}

As the Liège version was reworked by the Vulgate Latin translator, in the same city and at some point later in the fourteenth century, it underwent a further set of adaptations. Many of these pertain to the Ogier interpolations, and, taken together, work to create a very different sense of the present and future of Christian empire in the world among the pan-imperial, clerical, educated reading community that its Latin addressed. ${ }^{101}$ In some ways, the Vulgate Latin follows its predecessor; it too also assigns responsibility and credit for surviving and 
expanding Christian communities in the Orient to Ogier the Dane. ${ }^{102}$ However, the Vulgate is also sharper in its criticisms of the contemporary Church, and less so of contemporary princes. It is not the disunity of European lords that is to blame for Latin Christendom's loss of the Holy Land, but the faults of Church and people. The woeful state of the present Church and society is decried in a caustic couplet: ${ }^{103}$

Virtus, Ecclesia, Clerus, dæmon, symonia,

Cessat, calcatur, errat, regnat, dominatur.

(Virtue, ceases; the Church is trampled; the Clergy strays

The demon rules; simony dominates.)

Instead, the Vulgate Latin version goes much further than Jean d'Outremeuse in pressing the view that the ideal empire is a propagator and protector of Christianity. In the Vulgate, Ogier's role in the expansion of the Christian faith across the world, and in particular in the lands that now form its two greatest eastern empires, is rendered both explicit and intentional:

Circa annum ab incarnatione Domini octingentessimum, dux Ogerus de Danemarchia, cum quindecim cognationis suæ baronibus et armatis viginti milibus, transivit mare Greciæ, et, favente sibi Deo, conquisivit Christianitati per multa prælia pene omnes terras, regiones, et insulas, quas esse de potestate Grand Can prædixi, nec non et omnes, quæ sunt de potestate Imperii huius Imperatoris Indiæ. ${ }^{104}$

(Around the eight hundredth year after the incarnation of the Lord, Duke Ogier of Denmark, with fifteen barons of his kin and 20,000 armed soldiers, crossed the Greek sea, and, with the will of God, conquered for Christianity, through many battles, virtually all of these lands, regions, and islands that I have mentioned as being under the control of the Great Khan, and likewise all those that are under the control of the empire of this Emperor of India [that is, Prester John].)

The Vulgate's carefully worded passage makes clear, as its Liégois source does not, that these lands were conquered for Christianity intentionally, with divine support, for the purpose of the advancement of Christianity. ${ }^{105}$ The Vulgate Latin redactor makes a similar point about Ogier's conquest of lands and division of these among his relatives, including Gondebuef of Frisia, nicknamed Prester John for his piety:

Dum ergo Ogerus, dictas regiones expugnatas, divideret in hiis quindecim suis cognatis, et quemlibet eorum in suo loco constitueret regem, quatenus Christiana religio in illa orbis superficie semper stabilis permaneret, tradidit isti Præsbytero Joanni superiorem Indiam, cum 4000 insulis, regionibus, et ipsum præfecit Imperatorem super reliquos cognatos, ut ei certa tributa impenderent, et in omnibus obedirent. Atque ex tunc omnes successores Indiæ sunt vocati Præsbyter Joannes et usque in hodiernum tempus boni manserunt Christiani, et religionis æmulatores. ${ }^{106}$ 
(At that time, then, when Ogier had defeated the aforementioned regions, and had divided them among fifteen of his kin, and set up each one as king in his own place, so that the Christian religion would always endure on the surface of the world, he gave this Prester John Greater India, with 4,00o islands and regions, and made him emperor over the remaining kin, so that they would give him certain tribute and obey him in all things. And indeed as a result of this, all those who succeeded him [as Emperor of] India are called Prester John, and up until this day remain good Christians and committed followers of religion.)

The diffusion of Christianity across the globe is established not as a fortuitous accidental outcome of expansion, but as the central aim of Ogier's conquests. It is for precisely this purpose that he creates a priest-king, whose vassals then secure the Christianity of the various regions of his imperial domain. Once again the papacy's role in the establishment of global Christian empire is undercut; instead, the revived Western Roman Empire under Charlemagne and his subordinate partners is reimagined as central to God's plan for the Christianization of the entire known world.

The Vulgate Latin version, however, rather than acting as a cheerleader for the myth of Christian empire that, with a little help from Jean d'Outremeuse, it has helped to create, takes a more admonitory stance towards it. It accepts much of the Liège version's reimagined Carolingian imperial history, but questions the relationship between that past and the future. The Vulgate redactor curbs or critiques the worst excesses of the Liège version's Ogerian fantasies. He expresses scepticism for Jean's claim that Ogier gained immortality through eating the fruit of the Trees of the Sun and Moon, and excises altogether its reported prophecies that the now immortal Ogier will return to conquer the world for Christendom. ${ }^{107}$ Thus the Vulgate Latin crushes the notion that an empire's imagined glorious past foreshadows a future of global triumph. In a significant twist on Jean d'Outremeuse's version, moreover, the Vulgate Latin version uses Prester John's empire to present a cautionary tale in which Christian imperialist expansion ultimately fails. Prester John's empire, in the Vulgate translator's interpolation, is in the process of disintegration, with catastrophic consequences for the faith and souls of its people:

Interim, cum causa matrimoniorum aut procurationis filiorum, dispersa est primi Imperii integritas, et multæ de insulis conversæ, vel potius perversæ, retrocesserunt ad vetustum squalorem paganismi primi. ${ }^{108}$

(However, because of marriages or making provision for children, the initial integrity of the empire has broken apart, and many of the islands have converted back, or indeed more truly perverted, towards the ancient foulness of their initial paganism.)

While this may at first glance appear to be a slightly unnecessary warning against the kind of long-distance imperial expansion in which the Holy Roman Empire 
had never actually engaged, a closer look suggests that something else is going on here. Indeed, the empire of Prester John appears here to function once again as a mirror in which the contemporary Holy Roman Empire could view its own condition. Given the political situation outlined earlier in this section, such a sharp criticism of an empire's failures would surely have resonated strongly across the imperial lands of the late fourteenth century. Such actions as Charles IV's decision to partition his territories to make provision for dependants and his son Václav's creation of the Duchy of Milan in 1395 could well have been seen as fracturing the 'initial integrity of the Empire'. For the Vulgate redactor, however, it is the spiritual consequences of the fragmentation of Christian empire that are most worrying; with the fracturing of the Christian community comes loss of faith and consequent damnation among its inhabitants. Embedded in this translation's representation of global Christian empires past and present, then, is what appears to be a critique of the political state of the empire within which the redactor was writing, and a thinly veiled warning about the potential spiritual consequences of the fragmentation of Christian empire.

\section{Conclusion}

This article has illuminated significant concerns about the historical, present, and future trajectories of imperial power in three late fourteenth-century versions of Mandeville. In all three versions, empires past relate to empires present and future, and empires far away comment upon empires closer to home. In the text's earliest versions, the Mandeville-author demonstrates concern with the history and legitimacy of Christian empire in the West, and presents a world in which notions of a pre-eminent Christian empire in the West are challenged by the rise of great Islamic and multi-religious empires from the eastern Mediterranean to China. The two Liège reworkings of the text are generally treated as peripheral to the Anglo-French textual tradition in Mandeville scholarship, while the text's earliest versions implicitly suggest the peripherality of the Holy Roman Empire to the world's political geography. These reworkings write back against this sense of peripherality; with their assertion that Mandeville returned to Liège, wrote, and died there, they stake a claim to originary and central status in the textual tradition, just as they make claims to the historical and political centrality of a western Christian empire through which they connect their political present to the days of Charlemagne. This perhaps helps shed light on a certain paradox that Leonard Scales has observed in his work on the late medieval Empire; that while 'imperial government' moved 'with short and leaden steps', the imperial idea, by contrast, 'drifted far and wide'. ${ }^{109}$ These influential redactions help to explain some of the ideal's persistence and drift by exemplifying the kinds of local renegotiations and adaptations that, paradoxically, both transformed it and 
helped to make it so resilient. Redactors' interventions helped to sustain and reinforce, through recourse to history and myth, the power of the Holy Roman Empire as an ideal and imagined community in a period when the empire's real political power was in decline.

The two Liège redactors brought their histories of empire to bear on their readings of Mandeville and their readings of Mandeville to bear on their understanding of empire. Both texts imagine for the Holy Roman Empire a prehistory, in the form of its claimed Carolingian ancestor, of glorious Christian expansionism. I have referred a few times through the course of this article to Gabrielle Spiegel's phrase 'a consoling image of what once was and is no longer' because it seems a particularly apposite description of this past. ${ }^{110}$ Like other consoling histories, it offers not just identity- and community-affirmation through the articulation of shared history, but also what Spiegel terms 'an alternative vision to a now unpalatable present' and a way of projecting, explaining, or guarding against the future. This past is both like and not like the invented histories of Charlemagne's 'crusades' that, as scholars have noted, helped to provide the legitimacy, authority, motivation, and sense of martial identity to incentivize participants in the first and later crusades. It is something more than a version of history that allows 'all of the east' - in its newly expanded form - to be considered 'not only Christ's patrimony but a Frankish protectorate'. ${ }^{111}$ Rather, it is a version of imperial history that allows the redactors and their communities to reimagine not only imperial-global relationships, but local-imperial relationships too. Through his use of Ogier, figured as nominally a vassal but in practice a virtually autonomous partner in conquest and Christianization, Jean d'Outremeuse is able to set out a kind of blueprint for the ideal imperial-local relationship within a Christian empire. A relationship of mutual dependence and partnership between the emperor and his core subordinate polities is one that, the version implies, can form the basis for the kind of strong and successful programme of Christian expansion thought necessary to complete the divine plan for universal Christian community and thus human salvation. The Vulgate Latin version, however, presents its imperial histories not so much as consolation but rather as admonitions to an imagined pan-imperial community of readers. Even a great, powerful, seemingly God-ordained Christian empire can lapse into disintegration and decay. There is, perhaps, a recognition in the Vulgate that imperial communities are political as well as imagined; without strong leadership holding it together, empire will fail. In different ways, then, both the Liège and Vulgate Latin versions of Mandeville demonstrate a mutually reinforcing relationship between the process of rewriting one's imperial past and working out one's own and one's community's relationship with Christian empire in the present and future.

University of Southampton 


\section{NOTES}

I am grateful to the editors and anonymous peer reviewers at Medium Evum for their comments on drafts of this article.

1 See for example Stephen Howe, Empire: A Very Short Introduction (Oxford, 2002), pp. I3f.; Susan Reynolds, 'Empires: a problem of comparative history', Historical Research, 79 (2006), I5I-65.

2 Reynolds, 'Empires', p. I51; Peter Crooks, 'State of the union: perspectives on English imperialism in the late Middle Ages', Past and Present, 2I2 (20II), 3-42 (pp. 9f.).

3 Reynolds, 'Empires', pp. I53, I55f. Muldoon investigates the full range of medieval connotations of the term and its cognates in James Muldoon, Empire and Order 800-1800 (Basingstoke, 1999).

${ }^{4}$ Muldoon, Empire and Order; Robert Folz, The Concept of Empire in Western Europe from the Fifth to the Fourteenth Century, trans. Sheila Ann Ogilvie ([London], 1969).

5 L. E. Scales, 'Late-medieval Germany: an under-stated nation?', in Power and the Nation in European History, ed. L. E. Scales and Oliver Zimmer (Cambridge, 2005), pp. I66-9I (p. I68).

${ }^{6}$ Crooks, 'State of the union', p. 20. Benedict Anderson, Imagined Communities: Reflections on the Origins and Spread of Nationalism, rev. edn (Cambridge, 2006).

7 Robert Folz, Le Souvenir et la légende de Charlemagne dans l'empire germanique médiéval (Paris, 1950).

8 For instance, on medieval responses to traces of Imperial Rome, see Nicholas Howe, 'Anglo-Saxon England and the postcolonial void', in Postcolonial Approaches to the European Middle Ages: Translating Cultures, ed. Ananya Jahanara Kabir and Deanne Williams (Cambridge, 2005), pp. 25-47 and Alfred Hiatt, 'Mapping the ends of empire', in the same volume, pp. $48-76$. On what she sees as the supersession of military empire building in the form of crusade by 'cultural forms of empire' in the late Middle Ages see Geraldine Heng, Empire of Magic: Medieval Romance and the Politics of Cultural Fantasy (New York, 2003), p. I4. On perceived cultural imperialism and resistance as witnessed by literary translations, see Sif Rikhardottir, 'The imperial implications of medieval translations: Old Norse and Middle English versions of Marie de France's Lais', Studies in Philology, I05 (2008), I44-64.

9 Matthew Gabriele, An Empire of Memory: The Legend of Charlemagne, the Franks, and Jerusalem before the First Crusade (Oxford, 2013), p. 9.

${ }^{10}$ For the general reception history see Rosemary Tzanaki, Mandeville's Medieval Audiences: A Study on the Reception of the Book of Sir John Mandeville (I37I-I550) (Aldershot, 2003). 11 This vexed question does not bear upon this article and scholarship on the subject is too vast to cite fully. For a good summary of the history of the arguments and one hypothesis of English authorship, see Michael Bennett, 'Mandeville's Travels and the Anglo-French moment', MAE, 75 (2006), 273-92. For a recent hypothesis linking the text to Edward III's court, see W. Mark Ormrod, 'John Mandeville, Edward III, and the King of Inde', Chaucer Review, 46/3 (2012), 314-39.

12 See the tabulation of the text's sources in Christiane Deluz, Le Livre de Jehan de Mandeville: une 'géographie' au XIVe siècle (Louvain-la-Neuve, I988), appendix VI and the footnotes to her edition of the Insular version: Jehan de Mandeville, Le Livre des 
merveilles du monde, ed. Christiane Deluz, Sources d'histoire médiévale 3I (Paris, 2000). 13 Approaches are too varied to summarize in full here. Mary Baine Campbell focuses on what she identifies as the work's knowing fictionality: Campbell, The Witness and the Other World: Exotic European Travel Writing 400-I500 (Ithaca, NY, I988), e.g. p. I22. At the other end of the spectrum, Deluz uses her monograph to argue that it is a fundamentally geographical work in style and content.

${ }_{14}$ On the role of diversity in the book see in particular Suzanne Conklin Akbari, 'The diversity of mankind in the Book of Sir John Mandeville', in Eastward Bound: Travel and Travellers, I050-I550, ed. Rosamond Allen (Manchester, 2004), pp. 156-76. A number of studies focus on specular relationships in the text, as summarized in Marianne O'Doherty, The Indies and the Medieval West: Thought, Report, Imagination (Turnhout, 2013), pp. 2IIf. See Karma Lochrie, 'Provincializing medieval Europe: Mandeville's cosmopolitan Utopia'; PMLA, I24 (2009), 592-9 and Nowhere in the Middle Ages (Philadelphia, Pa, 2016), pp. 89-I3I (p. 90; p. III) . The debt here is to post-colonial studies: see Dipesh Chakrabarty, Provincializing Europe: Postcolonial Thought and Historical Difference (Princeton, NJ, 2000). 15 Tamarah Kohanski, 'Introduction', in The Book of John Mandeville: An Edition of the Pynson Text with Commentary on the Defective Version, ed. Tamarah Kohanski, Medieval and Renaissance Texts and Studies 23I (Tempe, Ariz., 200I), pp. xii-liii (pp. xi, xviif., xlviif.). 16 Iain M. Higgins, Writing East: The 'Travels' of Sir John Mandeville (Philadelphia, Pa, [1997]), p. I9.

17 E. N. Millett, 'Textual introduction', in Ancrene Wisse: A Corrected Edition of the Text in Cambridge, Corpus Christi College, MS 402, 2 vols, EETS, 325, 326 (Oxford, 2005-6), I, xi-lxvi (p. xlv).

18 Kohanski, 'Introduction', p. xii.

19 Gabrielle Spiegel, The Past as Text: Theory and Practice of Medieval Historiography (Baltimore, Md, 1999), p. 92.

${ }^{20}$ When taken together, manuscripts of these three versions are overwhelmingly dominant among the surviving fifteenth-century copies. See Josephine Waters Bennett, The Rediscovery of Sir John Mandeville (New York, I954), appendix I, pp. 30I-IO and pp. 312-16, and Deluz, Le Livre de Jehan de Mandeville, annexe I, pp. 370-82. The German translation has been the subject of a detailed study, which considers the two other versions as part of its backstory: Klaus Ridder, Jean de Mandevilles Reisen: Studien zur Überlieferungsgeschichte der deutschen Übersetzung des Otto von Diemeringen (Tübingen, I99I).

${ }^{21}$ Gabriele makes this point about representations of Charlemagne specifically, but it also holds true of representations of a Carolingian and post-Carolingian western empire: Gabriele, An Empire of Memory, p. 5.

22 Higgins terms the Vulgate Latin a counter-version; I have extended the term to cover both texts: Higgins, Writing East, p. 82.

${ }^{23}$ The other is the so-called Continental version. Arguments about the priority of one version over another have thus far proven inconclusive, largely because the critical edition of the Continental version that would be necessary to resolve them is still lacking: Susanne Röhl, Der Livre de Mandeville im I4. und I5. Jahrhundert: Untersuchungen zur handschriftlichen Überlieferung der kontinentalfranzösischen Version (Munich, 2004), p. I9. However, the two versions are, with the exception of one significant episode (the so-called Perilous Valley episode), sufficiently close in content for the Insular version to be treated 
as generally representative of the text's earliest versions. An overview and examples of the differences that Deluz identified, based on the textual situation known to her at the time, appears in the 'Introduction' and 'Annexes' in Jean de Mandeville, Le Livre des merveilles, pp. 7-85 (pp. 33-6) and 483-8 (pp. 485f.).

24 The outline history of the establishment of contact and its decline can be found in a variety of syntheses. See in particular Christopher Dawson, Mission to Asia (Toronto, I980) on the religious missions and Peter Jackson, The Mongols and the West I22I-I4IO (Harlow, 2005).

25 On these disagreements, see Muldoon, Empire and Order, pp. 46-52.

26 Ibid., p. 52.

27 Le Livre des merveilles, p. 97.

28 On the history of this claim, see Muldoon, Empire and Order, pp. 87-93.

29 Le Livre des merveilles, p. I03.

${ }^{30}$ Ibid., p. I05.

31 Anne Latowsky, Emperor of the World: Charlemagne and the Construction of Imperial Authority, 800-1229 (Ithaca, NY, 2013), p. 67. See also Gabriele, An Empire of Memory, p. IOI. Mandeville also repeats from legends of Charlemagne's visit to Jerusalem the story of the miraculous presentation to Charles of the Holy Virtue (foreskin of Christ) that, according to Gabriele, performs a similar function in confirming Frankish imperial authority: Le Livre des merveilles, p. 199; Gabriele, An Empire of Memory, p. 99.

32 Le Livre des merveilles, p. IIO; p. II2.

33 On the need to distinguish in translation between 'empire' and 'imperial authority', see Gabriele, An Empire of Memory, p. IoI.

${ }^{34}$ On the development of the Holy Roman Empire's claims to universal imperial authority (which reached their zenith under the Hohenstaufen in the twelfth and thirteenth centuries) see Muldoon, Empire and Order, pp. 87-93.

35 On this usage see Reynolds, 'Empires', p. 153 and Muldoon, Empire and Order, p. I6.

36 Le Livre des merveilles, p. I34.

37 Ibid., pp. 294f; p. I4I.

38 Ibid., p. 294 .

39 Bernard Hamilton, 'Prester John and the three kings of Cologne', in Studies in Medieval History Presented to R. H. C. Davis, ed. H. Mayr-Harting and R. I. Moore (London, I985), pp. I77-9I. For a translation of the letter and its interpolations and a summary of recent scholarship, see Prester John: The Legend and its Sources, trans. Keagan Brewer (London, 2015).

40 See, for example, Jacqueline Pirenne's argument for Provençal origin in La Légende du Prêtre Jean (Strasbourg, 1992). On the development of the notion of the sacrum imperium under Frederick, see Muldoon, Empire and Order, p. 37, quoting Horst Fuhrmann, Germany in the High Middle Ages, C.I050-I200, trans. Timothy Reuter (Cambridge, I986), p. 152.

${ }^{41}$ See Le Livre des merveilles, ed. Deluz, p. 443 n. I, for a summary of the description's sources, fleshed out in detail in subsequent footnotes.

42 Ibid., p. 435 .

43 Ibid., p. 433.

${ }^{44}$ Ibid., p. 402.

45 Ibid., p. 92. 
46 This inevitably simplifies a set of positions outlined in detail in Muldoon, Empire and Order; see in particular p. 86.

47 Robert Folz, The Concept of Empire, pp. 138-44 (p. I40).

48 On the reactive nature of many of the missions after the first initiatives under Innocent IV, see James D. Ryan, 'Conversion or the crown of martyrdom: conflicting goals for fourteenth-century missionaries in central Asia?', in Medieval Cultures in Contact, ed. Richard Gyug (New York, 2003), pp. 19-38. Muldoon, however, has argued that the early fourteenth-century papacy was more proactive in its attitude to mission than is sometimes assumed: James Muldoon, 'The Avignon papacy and the frontiers of Christendom: the evidence of Vatican Register 62', Archivium Historiae Pontificiae, I7 (1979), I25-95.

49 On the final phase of papal universalism in the early fourteenth century, see H. S. Offler, 'Empire and papacy: the last struggle', Transactions of the Royal Historical Society, 6 (1956), 2I-47. Mandeville's Dominican sources include William of Tripoli and Vincent de Beauvais; his Franciscan sources Odoric of Pordenone and (through Vincent de Beauvais) John of Plano Carpini.

${ }^{50}$ On this optimism, see Higgins, Writing East, pp. I66-9 and O'Doherty, The Indies, pp. 2I4f.

51 Le Livre des merveilles, p. 318; p. 362; Heng, Empire of Magic, p. 254.

52 Le Livre des merveilles, p. 40I; p. 402; p. 396.

53 On Charles IV's effective 'liquidation' of the empire, see Folz, Le Souvenir, pp. $438 \mathrm{f}$.

${ }^{54}$ French lands had of course been part of the Carolingian Empire, but did not form part of the revived Ottonian and later Empire. See Peter Wilson, The Holy Roman Empire: A Thousand Years of Europe's History (London, 2017), maps I, 3, and 6.

55 For a detailed critical discussion of scholarship on the Liège version, see Ridder, Jean de Mandevilles Reisen, pp. I49-64.

56 Raelet and Tyssens, 'Introduction', in La Version liégeoise du 'Livre' de Mandeville, ed. Madeleine Tyssens and René Raelet (Brussels, 20II), pp. XIII-LV (p. XXXIV n. 76). Deluz places it circa 1373 and Josephine Bennett between the I380s and I390s: Deluz, 'Introduction', Le Livre des merveilles du monde, ed. Christiane Deluz, Sources d'histoire médiévale 3I (Paris, 2000), p. 32; Bennett, Rediscovery, pp. I56f.

57 'Introduction', in Version liégoise, ed. Tyssens and Raelet, p. xxvii.

58 On Jean and Ogier, see Madeleine Tyssens, 'Jean d'Outremeuse, les origines légendaires et le passé carolingien de la patrie liégeoise: modalité d'une reconstruction du passé', in History and Heroic Tale: A Symposium, ed. Tore Nyberg et al. (Odense, 1985), pp. 173-205. On the development of the legend, see Knud Togeby, Ogier le Danois dans les littératures européennes (Copenhagen, 1969) and Emmanuelle Poulain-Gautret, La Tradition littéraire d'Ogier le Danois après le XIII siècle: permanence et renouvellement du genre épique médiéval (Paris, 2005).

59 Togeby, Ogier le Danois, p. 158. On the use of Ogier in the Myreur, see Dominique Boutet, 'Entre historiographie et roman épique: le Myreur des Histors de Jean d'Outremeuse', Histoire et roman (Bien dire et bien aprandre 22), ed. Cathéerine Croizy-Naquet and Philippe Logie (Villeneuve d'Aske, 2004) pp. 67-78. Boutet notes that Jean makes Ogier his own ancestor, providing one reason for this glorification.

${ }^{60}$ Claims for Liège as the original text's place of composition are debunked in Bennett, Rediscovery, pp. 89-122. 
${ }^{61}$ Ridder, Jean de Mandevilles Reisen, p. 177. The assertion occurs in an explicit in Hakluyt and Hakluyt's probable main source (Itinerarius (Gouda, I483-4)) and some manuscripts, including the I424 text in Minneapolis, James Ford Bell Library, MS I424 Co. II, fol. ${ }^{1} 67^{v}$, but is absent in full or part in others, e.g. Brussels, Bibliothèque royale, MSS II60-3. New York, Columbia University, Plimpton 264 (I456), and Liège, Université de Liège, Bibliothèque générale de philosophie et lettres, 354 are from Liège and nearby Huy respectively. Other texts from neighbouring and closely connected regions are associated with Grave (Hamburg, Staatsbibliothek. H. G. fol. 3I (Charleville-Mézières, Médiathèque Voyelles 62), connected to the city by the Meuse to the north and south respectively, Leuven to the west (Brussels, Bibliothèque royale, MSS II6o-3) and Deutz (Cologne) to the east (Minneapolis, James Ford Bell, I424, Co II).

${ }^{62}$ Ridder, Jean de Mandevilles Reisen, p. I69; p. I77. No critical edition of the text exists, so I follow the usual practice of using the version in Hakluyt's Principal Navigations (I589). I will discuss Hakluyt's treatment of the text in a forthcoming article entitled 'Richard Hakluyt and the 'Vulgate Latin' version of Mandeville's Travels'. As that article will show, Hakluyt's version works with a textual tradition that incorporates numerous annotations. While this complex textual history cannot be treated here, it has important practical implications: those elements identified as incorporated annotations are ignored and any significant variations between editions or manuscripts signalled in the notes. In quotations, I have omitted Hakluyt's diacritics, lightly modernized punctuation and capitalization, and distinguished between $\mathrm{u}$ and $\mathrm{v}$ and $\mathrm{i}$ and $\mathrm{j}$ without signal.

${ }^{63}$ Higgins, Writing East, p. I7I; Tzanaki, Mandeville's Medieval Audiences, p. I5; Deluz, 'Introduction', Le Livre des merveilles, p. 3I.

${ }^{64}$ Deluz, 'Introduction', p. 31.

65 Ferdinand Hénaux, Histoire du Pays de Liège, 2 vols, 3rd edn (Liège, I872-4), II (1874), pp. II8f.

${ }^{66}$ Folz, Concept of Empire, p. I7I. On the Hohenstaufen claims to universal empire, and the decline of imperial ideal after Frederick II, see Muldoon, Empire and Order, pp. 37-42. ${ }^{67}$ Ivan Hlaváček, 'The Luxemburgs and Rupert of the Palatinate, I347-I4IO', in The New Cambridge Medieval History, VI: c.I300-I4IS, ed. Michael Jones (Cambridge, 2000), pp. 56of. (p. 554); F. R. H. Du Boulay, Germany in the Later Middle Ages (London, 1983), pp. 42f.; Muldoon, Empire and Order, p. I42.

${ }^{68}$ Folz, Le Souvenir, pp. 438f. But the empire was already seriously weakened politically prior to Charles; see Offler, 'Empire and papacy', pp. 30-2.

69 Du Boulay, Germany in the Later Middle Ages, p. 45.

${ }^{70}$ Hugh LeCaine Agnew, The Czechs and the Lands of the Bohemian Crown (Stanford, Calif., 2004), p. 37 .

${ }^{71}$ Hlaváček, 'The Luxemburgs', pp. 56of.; H. S. Offler, 'Aspects of government in the late medieval empire', in Europe in the Late Middle Ages (London, 1965), pp. 217-47; p. 219; Agnew, The Czechs, p. 37; L. E. Scales, The Shaping of German Identity: Authority and Crisis, I245-I4I4 (Cambridge, 2012), p. 199 and n.

72 Hénaux, Histoire du Pays de Liège, II, 606-9.

73 On the consoling image, see Spiegel, The Past as Text, pp. 2IIf. Spiegel's discussion is quoted in part in Gabriele, An Empire of Memory, p. 6, to which I am indebted for drawing my attention to this discussion. On the past as providing typological authority 
for understanding the present and future, see Spiegel, The Past as Text, pp. $92 \mathrm{f}$.

74 Version liégeoise, ed. Tyssens and Raelet, p. 271.

75 Poulain-Gautret notes that the legend of Ogier becomes integrated into the wider 'Cycle des barons révoltés': La Tradition littéraire, p. $25 \mathrm{I}$.

${ }_{76}$ Togeby, 'Ogier le Danois', p. 158 ; Tyssens, 'Jean d'Outremeuse, les origines légendaires et le passé carolingien de la patrie liégeoise’, p. I94.

77 Edina Bozoky, 'L'Invention du passe liégeois chez Jean d'Outremeuse', in Le Passé à l'épreuve du présent: appropriations et usages du passé du moyen âge à la Renaissance, ed. Pierre Chastang (Paris, 2008), pp. 75-88 (p. 82).

78 Boutet, 'Entre historiographie et roman épique', p. 69.

79 Poulain-Gautret, La Tradition littéraire, pp. 266-9.

${ }^{80}$ Quoted in Boutet, 'Entre historiographie et roman épique', p. 76.

${ }^{81}$ On this strand in the remaniements see Poulain-Gautret, La Tradition littéraire, p. 198.

${ }^{82}$ For details see Gabriele, An Empire of Memory, pp. $99 \mathrm{f}$.

${ }^{83}$ Spiegel, The Past as Text, p. 94.

${ }^{84}$ On the Chevalerie see Togeby, 'Ogier le Danois', pp. 45-72, citing Barrois on p. 67; on the Roman, see pp. 134-48.

85 Version liégeoise, p. 63.

86 Ibid., p. 65.

87 See ibid., pp. 63, 65, 73, 85, I00, I09, IIо, II6, I44, I63, I54, I67, I68.

88 Ibid., p. 73.

${ }^{89}$ Ibid., p. 167.

90 Tzanaki, Mandeville's Medieval Audiences, p. Iо; p. 152.

${ }^{91}$ I inevitably simplify here in summarizing the two major papal and imperialist positions. See Muldoon, Empire and Order, p. 15, with fuller discussion across chs 3 and 4 of the same volume.

92 There are some affinities with certain eleventh-century justifications of Charlemagne's imperial authority discussed by Gabriele, in which his imperial authority, while based on a putative link to the Roman Empire, is also causally linked to military successes, including campaigns against pagans: see Gabriele, An Empire of Memory, pp. $99 \mathrm{f}$.

93 Robert Bartlett, The Making of Europe: Conquest, Colonization, and Cultural Change 95-I350 (London, 1994), p. 306.

94 Ibid., p. 313.

95 The Past as Text, p. 92.

96 Version liégeoise, p. 135 at line 4605, then again ('excepté Prestre Johan'), lines $4609 \mathrm{f}$.

97 Bozoky, 'L'Invention du passe liégeois', p. 84.

98 Version liégeoise, p. 134 .

99 Ibid., p. 85. See also p. Io9.

100 See Gabriele, An Empire of Memory, pp. I2O-2. Anke Holdenried provides a different explanation for the evolution of the Sybilla Tiburtina text in which the Last Emperor prophecy first appears in Holdenried, 'Many hands without design: the evolution of a medieval prophetic text', The Medicval Journal, 4 (2014), 23-42.

101 Bennett's list of confirmed manuscripts shows it distributed overwhelmingly among Austrian, German, and Low Countries libraries, with copies in libraries elsewhere often identified as copied in these regions: Bennett, Rediscovery, appendix I, pp. 30I-IO. 
102 See for example $P N$, I, ch. 26, p. 48; ch. 36, p. 60.

103 PN, I, ch. I, p. 25: 'nostris exigentibus meritis' ('because we deserved to be driven out'); the couplet is sometimes erroneously identified as a late interpolation, but appears in manuscripts, for instance: Brussels, BR, MS II60-3, at fol. $65^{\mathrm{v}}$.

${ }_{104}$ PN, I, ch. 4I, p. 65.

105 Absent in the relevant passage in the Version liégoise, p. I63.

106 PN, I, ch. 4I, p. 65.

107 PN, I, ch. 29, p. 58.

108 PN, I, ch. 4I, p. 65.

109 Scales, 'Late-medieval Germany', p. I79.

110 Spiegel, The Past as Text, pp. 2IIf.

111 Gabriele discusses in detail, with numerous references, the profound effect of mythic histories of Charlemagne in the East on crusading ideology, An Empire of Memory, pp. I29-59 (quotation at p. I57). 